\title{
Mathematics Performance of Students in a Philippine State University
}

\author{
Marvin Guinocor ${ }^{1}$, Porferio Almerino ${ }^{1 *}$, Irene Mamites ${ }^{1}$, Charisma Lumayag ${ }^{1}$, Mary Anne Villaganas ${ }^{1}$, \\ Mae Capuyan ${ }^{2}$ \\ ${ }^{7}$ Cebu Technological University, PHILIPPINES \\ ${ }^{2}$ Department of Education, Cebu Province, PHILIPPINES \\ *CORRESPONDENCE: $\triangle$ porferio.almerino@gmail.com
}

\begin{abstract}
Teaching and understanding mathematics is a significant concern in any educational system. Largish efforts are made by various researchers to find out the causes of students' performance in the subject. Despite every one of these endeavors issues still, endure. The researchers used a descriptive-correlational design to gather data through an adopted survey tool for study habits and attitudes. The study was conducted at the Cebu Technological University San Francisco Campus, Cebu, Philippines. The respondents were the 52 Education students who were enrolled in the mathematics program; they answered the survey of study habits and attitudes. The gathered data were treated using frequency, simple percentage, weighted mean, Pearson $r$, and t-test. It was found out that there is a significant positive high correlation between the study orientations of the students considering their academic performance in terms of their Graded Point Average (GPA) in Mathematics subjects. It was concluded that the study orientations of students differ. The researchers recommend conducting a further study on the effectiveness of the developed research-based study strategies.
\end{abstract}

Keywords: math performance, study orientation, college students

\section{INTRODUCTION}

Education is significantly one of the most critical factors in producing a human resource that is necessary for development in every aspect of a country. Education, in a broad sense, is any activity that has a significant effect on developing the cognitive, skills, and attitude of any individual. It is composed of various disciplines, which should be taught and learned by every human. One of the most established disciplines and is part of every curriculum around the world in Mathematics.

In the United States, Math achievement of American students in 2015 fell again for the second time on a significant international benchmark, as stated in the Program for International Student Assessment (PISA) (Kelly et al., 2013). American students were stagnating in reading and science proficiency, while their Math performance declined (Hossain, 2012).

The Trend International Mathematical Science Study Advanced (TIMMS) examined patterns of students' achievement in mathematics and found out that for over 20 years, there were some declines in the students' performances, and there were no improvements in the countries assessed (Maltese \& Tai, 2011). In the case of Indonesia, the PISA report (2012) showed that the achievement scores of Indonesian students in mathematics are recorded very low and was ranked the 64 th out of 65 countries (Ajisuksmo \& Saputri, 2017).

Article History: Received 19 January $2020 \bullet$ Revised 27 February $2020 \bullet$ Accepted 8 March 2020

(C) 2020 by the authors; licensee Modestum Ltd., UK. Open Access terms of the Creative Commons Attribution 4.0 International License (http://creativecommons.org/licenses/by/4.0/) apply. The license permits unrestricted use, distribution, and reproduction in any medium, on the condition that users give exact credit to the original author(s) and the source, provide a link to the Creative Commons license, and indicate if they made any changes. 


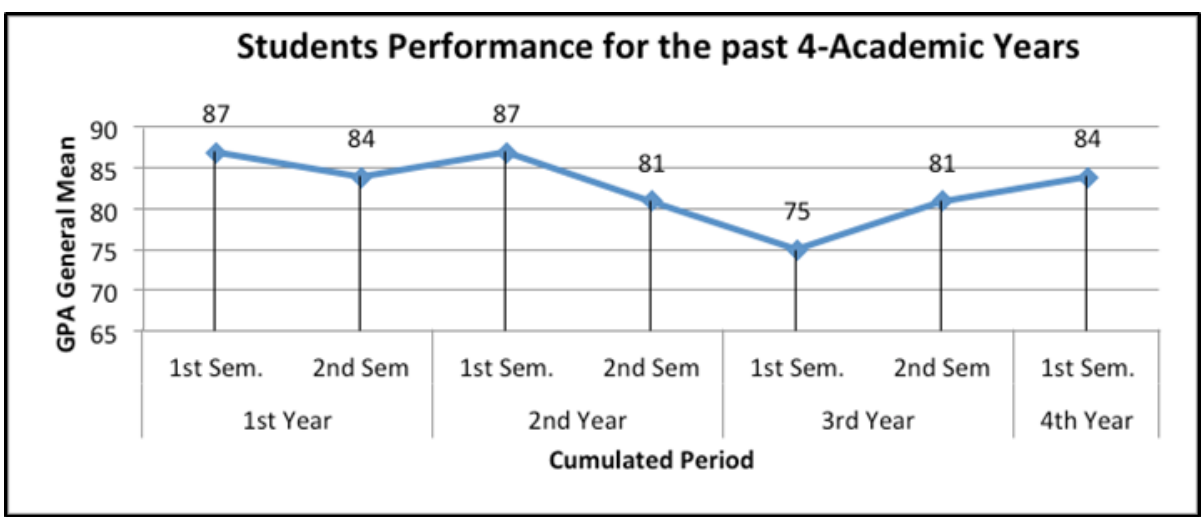

Figure 1. Students' performance for the past four academic years

In Asia, mathematics is viewed as one of the most critical subjects wherein students are encouraged to study the discipline (Leatham \& Peterson, 2010; Ronis, 2008). It is in this view that in most Asian countries, guiding practices on children's mathematics achievements are quite more vigorous (Wei \& Dzeng, 2014). As indicated by Etcuban and Pantinople (2018), that showing acquired an attractive change in the conduct of learning.

In the Philippines, mathematics is a general education subject in primary and higher education where learners are expected to gain understanding and appreciation of its principles as an applied-using appropriate technology in problem-solving, critical thinking, communicating, reasoning, making connections, representations, and decisions in real life (K to 12 Basic Education Curriculum).

According to Blömeke and Delaney (2014), It is essential hence required as a subject almost in every field. However, problems related to mathematics achievement are still evident not only in the Philippine setting but also right in other countries.

In the Philippine setting, educational modules in this order contain a specific topic and instructional plan standards to empower understudies to create consistent and numerical abilities expected to get it the fundamental mathematical concepts. However, low performance in this discipline is still evident.

The participation of the Philippines in TIMSS confirmed this deplorable condition-based from the report posted last 2013 that the performance of Filipino students in national and international surveys on mathematics and science competencies lag behind its neighboring countries like Singapore, South Korea, Hongkong, Chinese Taipei and Japan (Care et al., 2015).

The Filipino students excel in knowledge acquisition but fare considerably low in lessons requiring higherorder thinking skills (Dinglasan \& Patena, 2013; Ganal \& Guiab, 2014). Even college students are not exempted from the problems in learning and mastering mathematics (Americans, 2009; Presmeg, 2006).

Students' performance in mathematics, as indicated by the grades they achieved, is affected by various factors. Among the various factors, this study will primarily deal with students' affective characteristics, which focus on study habits and study attitudes, which are then further referred to as study orientations as reiterated by Biswas (2015). Two of the significant concerns of college students are getting control of time management and study habits.

Kaushar (2013) notes that most students nowadays are spending less time studying, a large portion of them does not pursue any calendar, and they do not know with the time the executives' idea. Then again, contemplate propensities appear to be a vital determinant of scholastic execution (Cerna \& Pavliushchenko, 2015).

Discoveries of Bashir and Mattoo (2012) uncovered a profoundly critical connection among different factors of study propensities and scholastic execution. The consequences of the investigation of Khurshid et al. (2012) demonstrated that there was a definite connection between study propensities and scholastic accomplishment.

Study attitude, on the other hand, can determine the extent to which learning occurs and how learning occurs as this influences the effort students put in understanding and practicing mathematical concepts and skills. If poor study orientations exist among the students, these could lead to low performance in mathematics. The orientation level of the students has a significant relationship with their academic performance (Bong, 2004; Horstmanshof \& Zimitat, 2007). 
According to Mutai (2011), if a student, regardless of his/her sex, has an excellent report introduction, he/she is probably going to be a high achiever. Then again, if an understudy has an unfortunate report introduction, he/she is probably going to be a low achiever.

It is in this premise that this study aims to provide a comparison of data among the study orientations of the students enrolled in a Mathematics program and consider the relationship between the study orientation of each group towards their academic performance. Understanding these will help lay the foundation for developing research-based study strategies, thus develop the right study orientations among the students.

\section{FRAMEWORK}

This study is mainly anchored on the Theory of Confluent Education, as defined by Stewart Shapiro (1983), a leading figure in the philosophy of mathematics, where he presented a version of structuralism. According to him, confluent education is "a deliberate, purposive evocation by responsible, identifiable agents of knowledge, skills, attitudes, and feelings which flow together to produce wholeness in the person and society." It likewise underpins a faith in the meeting up of psychological, emotional, and psychomotor learning, one that mirrors the entire understudy. While its approach has received comments in recent times, it still has not gained full spread recognition as a valuable approach in business education (Loon \& Nichol, 2015).

In the Philippine context, this study is conforming to the call of the New Philippine Constitution, Article XIV, Sec. 10, wherein it states, "Science and Technology are fundamental for national advancement and progress. The state will offer need to innovative work, creation, development, and their usage and science and innovation, instruction, preparing, and benefits". If analyzed, Science and Technology cannot stand without Mathematics, as we know, "Mathematics is the Queen and servant of Sciences."

Confluent learning, as reemphasized by Loon and Nichol (2015), is holistic, it aims to activate and engage all of the learner's senses. It is rooted in Dewey's notion of collateral learning and is a "philosophy and a process of teaching and learning in which the affective domain and the cognitive domain flow together, like two streams merging into one river." This necessitates an awareness of content and process and means being aware of and taking responsibility for the experience and context that people are interacting with, the topic and material are engaging.

Leading authorities of teaching and learning from Confluent Education (CE) emphasized cognitive (scholarly working) and full of feeling (sentiments and convictions) learning inside a set of physical exercises that ask students to "do a meta". The "meta" refers to a higher-order cognition about cognition or thinking about one's thinking. Metacognition is an essential element in solving problems and learning process of the students, as well as being a primary factor in determining learning achievement (Bedel, 2012). Metacognition is a powerful predictor in predicting student learning. In recent years, as cited by Iftikhar (2014), the role of metacognition as a component and a source of meaningful instruction have gained accuracy to a great extent. The concept has been around for as long as humans have been able to reflect on their thinking (Mahdavi, 2014), and the learners are given chances to consider how and what they are thinking, coupled with how they feel about their thinking. Feeling and affect are essential for learning, particularly when coupled with selfreflection and narrative to assist students in the examination of personal attitudes and beliefs. As noted in a meeting of the World Council of Comparative Education Societies (WCCES), these are aspects of CE considered essential to include in "how to learn/teach multi-dimensionally-the creative integration of cognitive, affective and behavioral dimensions of learning/teaching.

In tertiary education, most students advancing at this stage expect to finish a degree as an avenue for personal and economic progress. Taking their ambition into consideration, the colleges, however, are continually faced with an increasing number of cases of students with severe academic problems. It is in-line with the results of TIMMS Advanced that monitors students in their final year in a secondary school in preparation for the tertiary level. In their most recent survey (TIMMS Advanced 2015), it was found out that the students who have taken advanced courses in STEM subjects struggled to reach the TIMMS International Benchmark of Achievement.

Furthermore, indeed, student's success in mathematics according to Kunter et al. (2013), West et al. (2014), Morosanova et al. (2016), and Guy et al. (2015) is affected by three variables namely: Intelligence (IQ) and cognitive entry skills, quality of instruction, and affective characteristics. Although mathematics is intellectual, much research has recommended that future efforts be directed to find variables that are non- 
intellective to help account for the remaining variation. Study habits and attitudes are considered to be nonintellective factors that do correspond to grades for college students.

Numerous examinations have broken down the variables behind the presentation of understudies. Prior examinations have been done, which centered around subjective factors as indicators of scholastic achievement. As of late, there has been a developing enthusiasm for non-psychological variables (Mendezabal, 2013). Many researchers have studied the role of non-cognitive variables to name a few such as study habits (Bashir \& Mattoo, 2012; Khurshid et al., 2012), study skills (Demir et al., 2017; Fazal et al., 2012; Mendezabal, 2013), and attitudes on academic achievement. Some argued that these factors have a strong relationship with the scholarly execution of understudies, while others presumed that it was the blend of the various variables that could clarify understudies' scholastic execution (Mendezabal, 2013).

Siahi and Maiyo (2015) reemphasized study habits as a well-planned, what is more, intentional example of study, which has achieved a type of consistency concerning the understudies toward understanding scholarly subjects and finishing assessment. Study propensities are seen to be determinants of scholarly execution. Singh (2015) said that great understudies are not conceived yet are made by consistent and intentional of good investigation propensities for which there is no substitute. As per him, to improve understudies' scholarly accomplishment in various parts of training, it is fundamental to improve their great investigation propensities. This is additionally bolstered by the investigations of Siahi and Maiyo (2015) and of Osa-Edoh and Alutu (2012) which inspected the value of imbibing in the understudies' examination propensity students' study propensity, as a methods for upgrading their scholastic execution, revealing a high correlation between study habits and students' academic performance. The latter suggested that it is only when students imbibe or cultivate proper study habits that their academic performance can be improved upon.

There may be some reasons that may affect performance like different levels of intelligence, lack of proper infrastructural facilities, and lack of useful libraries, and so on. However, one of the reasons is that students fail to make a reasonable effort to learn what their teachers taught them in school. Also, many of them do not study at home because they failed to recognize the importance of study habits to their academic achievement.

Then again, numerous understudies feel weakened by sentiments of state uneasiness in the assessment and, along these lines, most likely show lower accomplishments (Macher et al., 2013). Understudies with higher scholarly accomplishments were characteristically propelled and utilized a more extensive assortment of learning techniques, all the more much of the time (Stover et al., 2014). The discoveries of Oluwatimilehin and Owoyele (2012) demonstrated a significant relationship of time-the board aptitudes, perusing, and notetaking abilities with scholastic accomplishment. Understudies with higher scholastic accomplishments utilize a broad scope of study aptitudes and suitable demeanors as a contrasted and lower scholarly accomplishment.

Also, Ganal and Guiab (2014) said that the absence of premiums and negative frames of mind towards arithmetic are issues that ought to be experienced by understudies in learning science since arithmetic is viewed as a dangerous subject and cloud. In the midst of this, understudies should even now have an inspirational disposition towards it because, as indicated by Guner (2012), past investigations on science detailed that mentalities towards arithmetic have a primary job in deciding learning accomplishment.

Ajisuksmo and Saputri (2017) referenced that the demeanors of the understudies influence their intellectual exercises. By having an inspirational frame of mind towards arithmetic, the understudies will feel that science is necessary with the goal that they will attempt to improve their arithmetic learning accomplishment. Understudies who have negative frames of mind will, in general, be trying to focus on science. According to Mata et al. (2012), negative attitudes are associated with negative emotional disposition. The disposition of these emotions has an impact on student behavior consider the use of mathematics, and do not enjoy mathematics. Along these lines, an uplifting frame of mind is fundamental for understudies to figure out how to deliberately and acquire benefits.

Many research brought up that there is any inconsistency between the examination demeanors of high and low-accomplishing understudies. High-accomplishing understudies had a progressively uplifting demeanor toward study, in that they recognized and responded decidedly to the significant parts of the circumstance they wound up in, while the low-accomplishing understudies would, in general, be critics, responding to the negative parts of concentrate, for example, interruptions and minor disturbances. The high-accomplishing understudies discovered tertiary work an energizing test, acknowledged the limitations, and complied with the requests made upon them all the more promptly, while the low achievers seemed to need elevated level inspiration. The more fruitful gathering was additionally seen as progressively practical and separating in their evaluation of those circumstances, which were exceptionally pertinent to educational accomplishments, 
for example, order and work needs. They were better composed in both their work and relaxation exercises (Mendezabal, 2013).

Significant research findings reveal that good study habits and attitudes are interconnected with students' academic success. Such direction of the study is supported by the works of Kumar and Nagaraju (2015) and Mendezabal (2013) using the concept that study habits and study attitudes are both significant variables, which determine the academic performance of the students.

The study habits and study attitudes are multidimensional. This implies successful contemplating requires not just that the understudies have information on suitable considering systems and practices (study aptitudes), yet also supported and purposeful exertion (study inspiration), self-guideline, capacity to focus, self-observing (study propensities), and awareness of other's expectations for and esteem in one's learning (study disposition).

An audit of the writing featured the significance of understudies' examination habits and attitudes in their academic performance (Mendezabal, 2013). Since the study orientation has two components, namely, study habits and studies attitudes, these are subdivided into subscales. For study habits, this includes delay avoidance and work methods. The study attitude, on the other hand, is broken down into teacher approval and education acceptance (Cerna \& Pavliushchenko, 2015; Mendezabal, 2013).

To determine such factors, the respondents are divided into groups, the "Fair," "Good," "Very Good," and "Superior" using the GPAs as well as the Survey of Study Habits and Attitudes (SSHA). The latter will be the tool to be used to measure students' academic behavior. It measures traits, which play an essential role in academic success. The test has four primary subscales, as defined by Cerna and Pavliushchenko (2015) and Mendezabal (2013). The subscale on Delay Avoidance is defined as the students' promptness in completing academic assignments, lack of procrastination, and freedom from wasteful delay and distraction. Work Methods pertains to the use of students of effective study procedures, efficiency in doing academic assignments, and how-to-study skills. Teacher Approval refers to the students' opinions on teachers and their classroom behavior and methods. Education Acceptance relates to the students' approval of educational objectives, practices, and requirements.

The quality of a country depends upon the quality of its citizens. The nature of the citizens can be identified with the nature of their instruction, and the nature of training other than different variables relies on study propensities and concentrate the frame of mind of the students. Along these lines, to upgrade the nature of instruction, it is essential to improve the examination propensities and study frames of mind of the understudies.

\section{OBJECTIVES OF THE STUDY}

This research determined the study orientation of mathematics students in a Philippine State University as the basis for proposing an intervention plan. Specifically, this study sought answers the: 1) Respondents' academic performance in mathematics; 2) Level of study orientations; 3) Significant relationship between the study orientation of the respondent groups and their mathematics performance; 4) Significant difference of study orientation among the group of students in terms of their study habits and study attitudes.

\section{METHODOLOGY}

This study employed the descriptive-correlational method to gather data regarding the study orientations of the mathematics students in a university. The study was conducted at Cebu Technological University San Francisco Campus, Cebu, Philippines. It offers many courses such as Elementary and Secondary Education, Hospitality Management, Industrial Technology, and its flagship course, the Bachelor of Science in Fishery.

Fifty-two respondents consisted of 26 third year and 26 fourth-year students of Bachelor of Secondary Education major in Mathematics, wherein they were chosen purposively They answered a questionnaire whose contents were adopted from the Survey of Study Habits and Attitudes (SSHA) by Brown and Holtzman with reliabilities ranging between 0.83 and 0.87 and is judged to be a useful measure of study skills and attitudes. The modification was made as to how it will be presented and treated to fit the present study. In compliance with the Research Protocol, the researchers confidentially kept the gathered data for anonymity and privacy. 


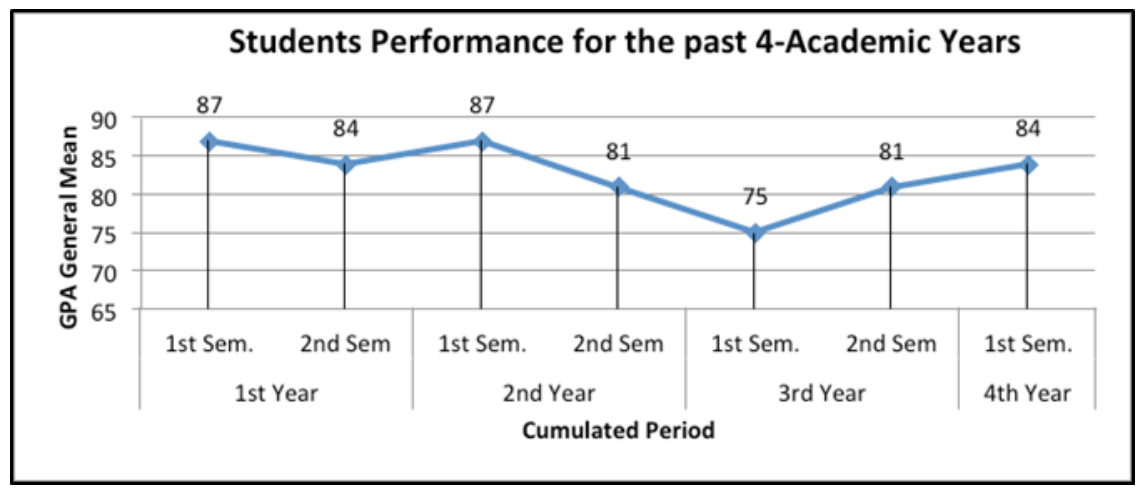

Figure 2. Students' academic performance in mathematics

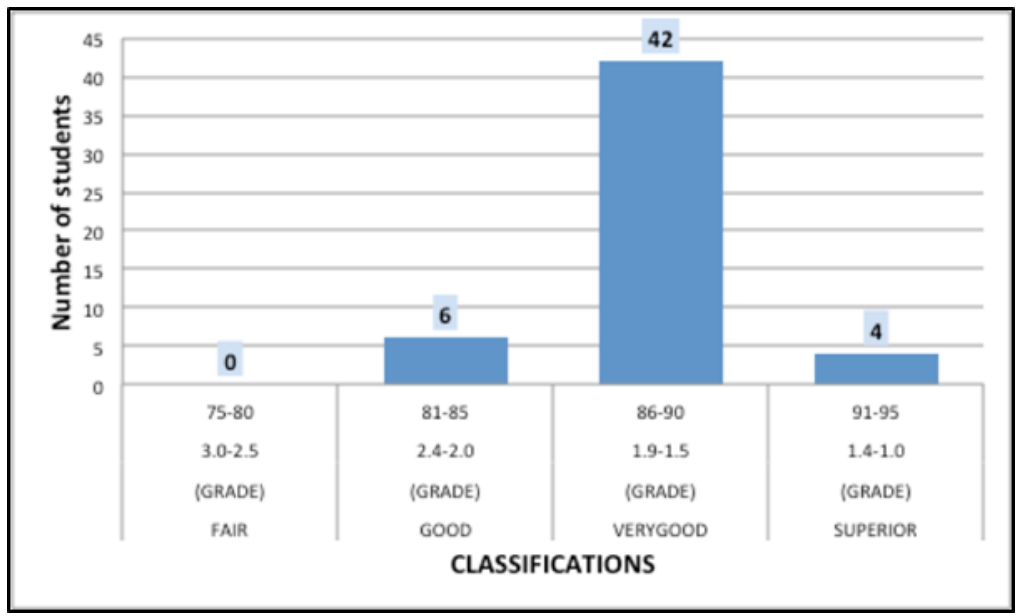

Figure 3. Distribution of respondents Relative to Classifications

This questionnaire is a 5-point Likert-type scale test. For each statement, the following scale is provided for indicating whether the student does or feels as the statement suggests (as adopted from the SSHA by Brown and Holtzman): Rarely ( $0 \%$ to $15 \%$ of the time), Sometimes (16\% to $35 \%$ of the time), Frequently ( $36 \%$ to $65 \%$ of the time), Generally (66\% to $85 \%$ of the time), and Almost Always ( $86 \%$ to $100 \%$ of the time). The SSHA is composed of 50 items for Study Habits (25-items for Delay Avoidance and 25-items for Work Method) and 50 items for Study Attitude (25-items for Teacher Approval and 25-items for Educational Acceptance). The gathered information was examined and deciphered utilizing frequency, simple percentage, weighted mean, Pearson $r$, and t-test.

\section{RESULTS AND DISCUSSIONS}

\section{Academic Performance in Mathematics}

Figure 2 shows the cumulated grades of the students wherein it was found that the Grade Point Average (GPA) of students grades in Mathematics during their first year was 87 (1.8) and 84 (2.1) for the first and second semesters, respectively. Furthermore, during their second year, they shared a GPA of 87 (1.8) and 81 (2.4) for the first semester and second semester, respectively. On the other hand, the students showed that during their third year, they got a GPA of 75 (3.0) for the first semester and 81 (2.4) for the second semester, while during their fourth year, they got a GPA of 84 (2.1).

Figure 3 shows the distribution of the respondents in terms of their Grade Point Average (GPA) in Mathematics subjects concerning the classifications stipulated in CTU-Student Manual (ed. 2015) such as "Fair (3.0-2.6)", "Good (2.5-2.1)", "Very Good (2.0-1.6)", and "Superior." Base from the data gathered, it was shown that $11.54 \%$ (6 students) of the total number of respondents fall on the "Good" performing group, $80.78 \%$ (42 students) belonged to the "Very Good " performer students, and 7.69\% (4 students) performed as a "Superior." It is in this table wherein we can conclude that the majority of these education students majoring in Mathematics performed "Very Good." 
Table 1. Students' study orientation level

\begin{tabular}{|c|c|c|c|c|c|c|c|c|c|c|c|c|c|}
\hline \multirow{3}{*}{\multicolumn{2}{|c|}{ Scale }} & \multicolumn{12}{|c|}{ Group of Students } \\
\hline & & \multicolumn{3}{|c|}{ Good (n=6) } & \multicolumn{3}{|c|}{ Very Good $(n=42)$} & \multicolumn{3}{|c|}{ Superior $(n=4)$} & \multicolumn{3}{|c|}{ Overall $(\mathrm{N}=52)$} \\
\hline & & Mean & LD & Level & Mean & LD & Level & Mean & LD & Level & Mean & LD & Level \\
\hline \multicolumn{2}{|c|}{ Delay Avoidance } & 2.79 & $\mathrm{~F}$ & $\mathrm{~A}$ & 3.14 & $\mathrm{~F}$ & $\mathrm{~A}$ & 4.08 & $\mathrm{G}$ & $\mathrm{AA}$ & 3.34 & $\mathrm{~F}$ & $\mathrm{~A}$ \\
\hline \multicolumn{2}{|c|}{ Work Method } & 3.14 & $\mathrm{~F}$ & $\mathrm{~A}$ & 3.39 & $\mathrm{~F}$ & $\mathrm{~A}$ & 4.00 & $\mathrm{G}$ & $\mathrm{AA}$ & 3.51 & $\mathrm{G}$ & $\mathrm{AA}$ \\
\hline \multicolumn{2}{|c|}{ Teacher Approval } & 3.22 & $\mathrm{~F}$ & $\mathrm{~A}$ & 3.38 & $\mathrm{~F}$ & $\mathrm{~A}$ & 4.06 & $\mathrm{G}$ & $\mathrm{AA}$ & 3.56 & $\mathrm{G}$ & $\mathrm{AA}$ \\
\hline \multicolumn{2}{|c|}{ Educational Acceptance } & 3.28 & $\mathrm{~F}$ & $\mathrm{~A}$ & 3.49 & $\mathrm{G}$ & $\mathrm{AA}$ & 3.91 & $\mathrm{G}$ & $\mathrm{AA}$ & 3.56 & $\mathrm{G}$ & $\mathrm{AA}$ \\
\hline \multicolumn{2}{|c|}{ Study Habit } & 2.97 & $\mathrm{~F}$ & $\mathrm{~A}$ & 3.27 & $\mathrm{~F}$ & $\mathrm{~A}$ & 4.04 & $\mathrm{G}$ & $\mathrm{AA}$ & 3.42 & $\mathrm{G}$ & $\mathrm{AA}$ \\
\hline \multicolumn{2}{|c|}{ Study Attitude } & 3.25 & $\mathrm{~F}$ & $\mathrm{~A}$ & 3.44 & $\mathrm{G}$ & $\mathrm{AA}$ & 3.99 & $\mathrm{G}$ & $\mathrm{AA}$ & 3.56 & $\mathrm{G}$ & $\mathrm{AA}$ \\
\hline \multicolumn{2}{|c|}{ Study Orientation } & 3.11 & $\mathrm{~F}$ & $\mathrm{~A}$ & 3.35 & $\mathrm{~F}$ & $\mathrm{~A}$ & 4.01 & $\mathrm{G}$ & $\mathrm{AA}$ & 3.49 & $\mathrm{G}$ & $\mathrm{AA}$ \\
\hline Legend & \multicolumn{2}{|c|}{ Range } & \multicolumn{4}{|c|}{ Letter Description (LD } & \multicolumn{4}{|c|}{ Verbal Description (VD) } & & & \\
\hline \multirow[t]{5}{*}{ Description (D) } & & \multicolumn{4}{|c|}{$\mathrm{A}$} & \multicolumn{4}{|c|}{ Almost Always } & & & \\
\hline & \multicolumn{2}{|c|}{$3.41-4.20$} & \multicolumn{4}{|c|}{$\mathrm{G}$} & \multicolumn{4}{|c|}{ Generally } & & & \\
\hline & \multicolumn{2}{|c|}{$2.61-3.40$} & \multicolumn{4}{|c|}{$\mathrm{F}$} & \multicolumn{4}{|c|}{ Frequently } & & & \\
\hline & \multicolumn{2}{|c|}{$1.81-2.60$} & \multicolumn{4}{|c|}{$\mathrm{S}$} & \multicolumn{4}{|c|}{ Sometimes } & & & \\
\hline & \multicolumn{2}{|c|}{$1.00-1.80$} & \multicolumn{3}{|c|}{$\mathrm{R}$} & & \multicolumn{4}{|c|}{ Rarely } & & & \\
\hline Level (L) & $4.21-$ & .00 & & & 1 & & High & & & & & & \\
\hline & $3.41-$ & 1.20 & & & $\mathrm{~A}$ & & Abov & Averag & & & & & \\
\hline & $2.61-$ & 3.40 & & & 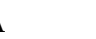 & & Aver: & & & & & & \\
\hline & $1.81-$ & .60 & & & $\mathrm{~A}$ & & Belov & Averag & & & & & \\
\hline & $1.00-$ & .80 & & & & & Low & & & & & & \\
\hline
\end{tabular}

\section{Respondents' Level of Study Orientation}

The table presents the study orientation level of the respondents analyzed per group and their level when it comes to the considered scales of the study.

Table 1 shows that in the scale of "Delay Avoidance" both the "Good" performer students (Mean=2.79) and the "Very Good" performer students (3.14) yield an Average Level while the "SUPERIOR" group of students (Mean=4.08) yield the penultimate level of Above Average wherein this entails that when it comes to promptness in completing assignments and efficiency in time management the "Superior" group of students outperformed the other two identified groups. This is in line with the study of Nasrullah et al. (2015), where they concluded the other point that "students who scored poor in academic achievement gained significantly lower in time management." Meanwhile, from a general perspective, the overall performance of the students on the scale of "Delay Avoidance" falls in the Average level (3.337).

On the scale of "Work Method," it was found out that both the "Good" performer students (Mean=3.14) and the "Very Good "performer students (3.391) yield an Average Level while the "Superior" group of students (Mean=3.999) yield the level of Above Average wherein these tell that when it comes to studying skills the "Superior" group of students performed far more higher compared to the other two identified groups. This somehow conforms to the study of Fazal et al. (2012), wherein he concluded that understudies with higher scholarly accomplishment utilized a broad scope of study abilities when contrasted with understudies with lower scholastic accomplishment. Meanwhile, from a general perspective, the overall performance of the students on the scale of "Work Method" falls in the Average level (3.337). In an overall view, the students' practical skills as the scale of "Work Method" suggests, they are performing in an Above Average manner (Mean=3.51).

Analyzing "Delay Avoidance" and "Work Method" as one, the scale of "Study Habits" clearly followed that both the "Good" performer students (Mean=2.967) and the "Very Good" performer students (3.268) yield an Average Level and still it shows that the "Superior" group of students (Mean=4.035) yield the level of Above Average wherein. This difference adheres to the study of Singh (2015) that significantly, there is a difference between the Study Habit of the students with regards to their academic achievements in Mathematics. The figures above tell that when it comes to the completion of tasks, time management, and study skills, the "Superior" group of students performed far higher compared to the other two identified groups. This realization goes the same on the statements made by Siahi and Maiyo (2015) as their conducted research, reveals that the students having Good Study Habit achieve higher than students having lower Study Habits. Furthermore, Ebele and Olufo (2017) also concluded that when students develop and utilize Good Study Habits, they tend to perform better compared to students who study without them or with bad Study Habits. On the other hand, 


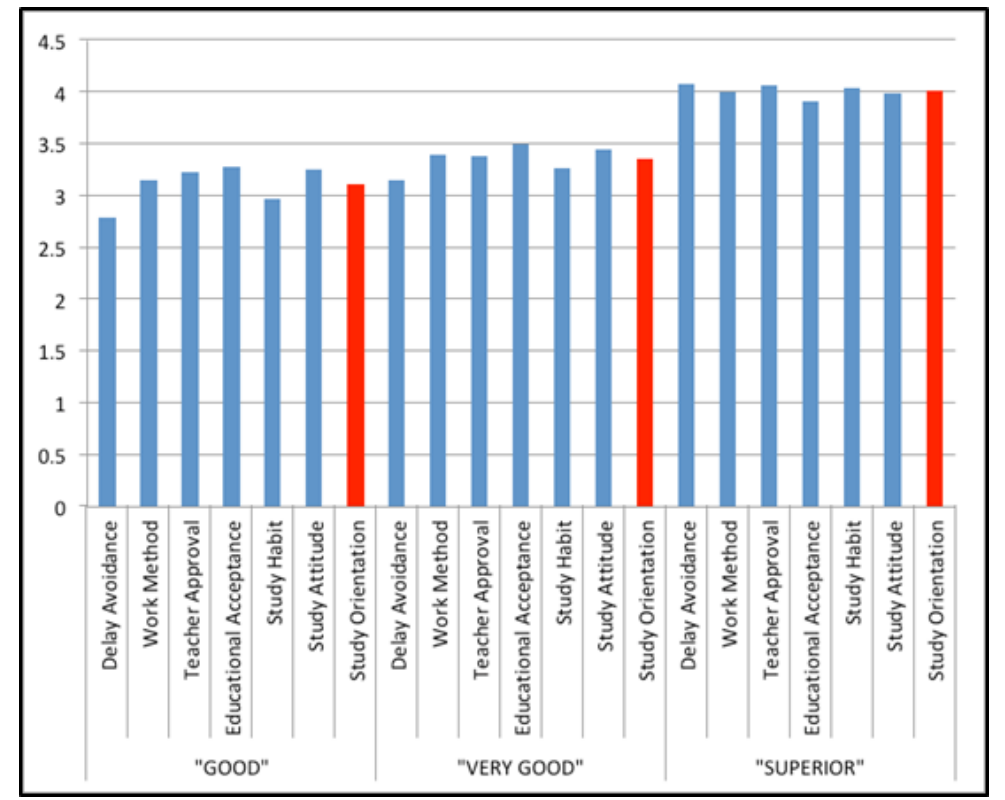

Figure 4. Students' study orientation level

if collectively analyzed, the overall "Study Habits" of the students falls in the Above Average Level (Mean=3.323).

It can be deduced that in the scale of "Teacher Approval" both the "Good" performing students (Mean=3.220) and the "Very Good" performer students (3.384) yield an Average Level and still it shows that the "Superior" group of students (Mean=4.060) yield the level of Above Average wherein these tell that when it comes to student opinions about teacher classroom behavior, management and methods the "Superior" group of students is showing more positive approval compared to the other identified groups. In an overall view, the Teacher Approval of the students falls in the Above Average Level (Mean=3.555).

On the other hand, it was identified that in the scale of "Educational Acceptance" the "Good" performer students (Mean=3.280) yield an Average Level while both the "Very Good" performer students (Mean=3.490) and the "Superior" group of students (Mean=3.910) yield an Above Average Level wherein these tell that when it comes to student's approval of educational objectives, practices, and requirements both the "Very Good" and the "Superior" group of students shared a more common belief in showing positive approval compared to the other identified group. In an overall view, the "Educational Acceptance" of the students falls in the Above Average Level (Mean=3.556).

Analyzing "Teacher Approval" and "Educational Acceptance" as one, the scale of "Study Attitude" clearly signifies that the "Good" performer students (Mean=3.250) yield an Average Level while both the "Very Good," performer students (Mean=3.437) and the "Superior" group of students (Mean=3.985) yield an Above Average Level wherein these tell that when it comes to students' opinions about teacher classroom behavior, management, methods, educational objectives, practices, and requirements both the "Very Good" and the "Superior" group of students shared a more common belief in showing positive approval compared to the other identified group. In an overall view, the "Study Attitude" of the students falls in the Above Average Level (Mean=3.557). The differences in their level somehow go with the findings discovered by Mendezabal (2013) that high-accomplishing understudies had a progressively inspirational frame of mind toward study contrasted with the low-accomplishing understudies.

It can be deduced from the scale of "Study Orientation" that both the "Good" performer students (Mean=3.108) and the "Very Good" performer students (3.353) yield an Average Level and still it shows that the "Superior" group of students (Mean=4.010) yield the level of Above Average wherein these tell that when it comes to students Study Orientation which comprises the totality of all the considered scales which ranges across the Delay Avoidance (students' completion of tasks, time management), Work Methods (study skills), Teacher Approval (opinions about teacher classroom behavior, management, and methods), and Educational Acceptance (acceptance of educational objectives, practices, and requirements) the "Superior" group of students showed a more positive performance and approval compared to the other identified groups. 
Table 2. Relationship between respondents' study orientation and their mathematics performance

\begin{tabular}{|c|c|c|c|c|c|c|c|c|c|c|c|c|c|}
\hline \multirow{2}{*}{\multicolumn{2}{|c|}{ Correlation Variables }} & \multicolumn{12}{|c|}{ Group of Students } \\
\hline & & \multicolumn{3}{|c|}{ Good $(n=6)$} & \multicolumn{3}{|c|}{ Very Good $(n=42)$} & \multicolumn{3}{|c|}{ Superior $(n=4)$} & \multicolumn{3}{|c|}{ Overall $(\mathrm{N}=52)$} \\
\hline Independent & Dependent & $\mathbf{r}$ & $t_{\mathrm{cv}}$ & $\mathbf{t}_{\mathrm{tv}}$ & $\mathbf{r}$ & $t_{c v}$ & $t_{\mathrm{tv}}$ & $\mathbf{r}$ & $t_{\mathrm{cv}}$ & $t_{\mathrm{tv}}$ & $\mathbf{r}$ & $t_{c v}$ & $t_{t v}$ \\
\hline $\begin{array}{c}\text { Study } \\
\text { Orientation }\end{array}$ & Grades & 0.273 & 0.568 & 2.776 & 0.329 & 2.136 & 2.021 & 0.974 & 6.080 & 4.303 & 0.561 & 4.792 & 2.009 \\
\hline \multicolumn{14}{|l|}{ Note: } \\
\hline \multicolumn{14}{|c|}{$\begin{array}{l}\text { Correlation Legends (r-value): } \\
\text { Perfect }= \pm 1.00, \text { High }= \pm \\
\text { Moderately Low }= \pm 0.3 \\
\text { Decision Rule: }\end{array}$} \\
\hline
\end{tabular}

The novelty of this finding is of no more the same impact to the concerned individuals as numerous researchers found this as significantly accurate as cited by Biswas (2015) wherein they all declared that the high and low achiever students are significantly differing in respect to Study Orientation and added that the high achievers have better Study Orientation than the low achievers. On the other hand, on an overall view, the Study Orientation of the students falls in the Above Average Level (Mean=3.490).

\section{Test of Significant Relationship}

Based on the data gathered, Table 2 shows that there is a Positive Low Correlation $(r=0.273)$ between the study orientation of the "Good" performing students and their grades in Mathematics. Meanwhile, there is a Positive Moderately Low Correlation ( $\mathrm{r}=0.329)$ between the study orientation of the "Very Good" performing students and their grades in Mathematics. Also, there is Positive High Correlation $(r=0.974)$ between the study orientation of the "Superior" performing students and their grades in Mathematics.

Based on the above findings, it can be deduced that there is a Positive Moderately High Correlation $(r=0.561)$ between the Study Orientation of the Over-All students considering their academic performance in terms of their Graded Point Average (GPA) in Mathematics subjects. This finding conforms to the results of the studies conducted by Kumar and Nagaraju (2015) and even Mendezabal (2013), wherein they both found out that there is a positive relationship between the study orientation of the respondents and their academic performance. Also, the study orientation skills should be taught in the formal setting due to the presence of a strong relationship between study orientation skills and their grade point average. This suggests that as the independent variable increases (Study Orientation), the dependent variable (Grades) also increases.

Further analysis will lead us to the determination of whether this existing relationship is significant or non-significant. According to the table above, the computed t-value (0.568) for the "GOOD" performing students is less than compared to the tabulated t-value (2.776); hence it suggests that the identified relationship is non-significant. On the other hand, it was revealed that within the group of "VERY GOOD" performing students $\left(t_{\mathrm{cv}=2.136}>\mathrm{t}_{\mathrm{tv}=2.021}\right)$, the identified positive correlation was significant. Furthermore, it can also be noted that within the group of "Superior" performing students $\left(t_{\mathrm{cv}=6.08}>t_{\mathrm{tv}=4.303}\right)$, the identified positive correlation was significant. In general, it can be concluded that there is a significant positive relationship between the students' Study Orientation and their Grades. This general finding conforms to the results of the studies conducted by Kumar and Nagaraju (2015), Mendezabal (2013), Fazal et al. (2012) as they concluded that Study Orientation is positively related to the academic performance of the students.

\section{Test of Significant Difference}

Table 3 shows that there is a significant difference among the level of each group on the scale of "Delay Avoidance" as the p-value (0.0002) is less than the level of significance. It was found out that in a pairwise comparison, the "Good" group vs. "Very Good" group with p-value=0.082 shows that between them, the disparity is non-significant. In contrast, in the "Superior" group vs. "Good" group and "Superior" group vs. "Very Good "group with p-value=0.0001 and p-value=0.0002 (respectively), these suggest that within this pair-wise analysis, the significant differences existed. With the light of these findings, it can be deduced that the level of the performance (Mean=4.08) of the "Superior" performing group when it comes to the scale of "Delay Avoidance" is far more different compared to the other group. 
Table 3. Difference and comparison between groups

\begin{tabular}{|c|c|c|c|c|c|c|c|c|c|}
\hline \multirow{3}{*}{ Scale } & \multicolumn{7}{|c|}{ Group of Students } & \multirow{3}{*}{$\begin{array}{c}\text { Comparison } \\
\text { (Pairwise) }\end{array}$} & \multirow{3}{*}{$\begin{array}{c}\text { Result } \\
\text { (p-value) }\end{array}$} \\
\hline & \multicolumn{2}{|c|}{ Good (n=6) } & \multicolumn{2}{|c|}{ Very Good $(n=42)$} & \multicolumn{2}{|c|}{ Superior $(n=4)$} & \multirow{2}{*}{$\begin{array}{c}\text { p- } \\
\text { value }\end{array}$} & & \\
\hline & Mean & SD & Mean & SD & Mean & SD & & & \\
\hline \multirow{3}{*}{ Delay Avoidance } & \multirow{3}{*}{2.79} & \multirow{3}{*}{0.31} & \multirow{3}{*}{3.14} & \multirow{3}{*}{0.48} & \multirow{3}{*}{4.08} & \multirow{3}{*}{0.12} & \multirow{3}{*}{0.000} & G vs VG & 0.0802 \\
\hline & & & & & & & & G vs S & 0.0001 \\
\hline & & & & & & & & VG vs S & 0.0020 \\
\hline \multirow{3}{*}{ Work Method } & \multirow{3}{*}{3.14} & \multirow{3}{*}{0.26} & \multirow{3}{*}{3.39} & \multirow{3}{*}{0.43} & \multirow{3}{*}{4.00} & \multirow{3}{*}{0.08} & \multirow{3}{*}{0.007} & G vs VG & 0.1611 \\
\hline & & & & & & & & G vs S & 0.0021 \\
\hline & & & & & & & & VG vs S & 0.0068 \\
\hline \multirow{3}{*}{ Teacher Approval } & \multirow{3}{*}{3.22} & \multirow{3}{*}{0.47} & \multirow{3}{*}{3.38} & \multirow{3}{*}{0.44} & \multirow{3}{*}{4.06} & \multirow{3}{*}{0.124} & \multirow{3}{*}{0.010} & G vs VG & 0.3923 \\
\hline & & & & & & & & G vs S & 0.0043 \\
\hline & & & & & & & & VG vs $\mathrm{S}$ & 0.0046 \\
\hline & & & & & & & & G vs VG & \\
\hline Educational Acceptance & 3.28 & 0.28 & 3.49 & 0.44 & 3.91 & 0.068 & 0.066 & G vs S & \\
\hline & & & & & & & & VG vs $\mathrm{S}$ & \\
\hline & & & & & & & & G vs VG & 0.0987 \\
\hline Study Habit & 2.97 & 0.21 & 3.27 & 0.44 & 4.04 & 0.081 & 0.001 & G vs S & 0.0002 \\
\hline & & & & & & & & VG vs $\mathrm{S}$ & 0.0008 \\
\hline & & & & & & & & G vs VG & 0.2797 \\
\hline Study Attitude & 3.25 & 0.29 & 3.44 & 0.42 & 3.99 & 0.096 & 0.016 & G vs S & 0.0055 \\
\hline & & & & & & & & VG vs $\mathrm{S}$ & 0.0103 \\
\hline & & & & & & & & G vs VG & 0.1197 \\
\hline Study Orientation & 3.11 & 0.23 & 3.35 & 0.38 & 4.01 & 0.055 & 0.001 & G vs S & 0.0002 \\
\hline & & & & & & & & VG vs $\mathrm{S}$ & 0.00090 \\
\hline
\end{tabular}

Level of Significance @ $\mathbf{\alpha}=5 \%$

Decision Rule:

Accept Null Hypothesis if: $p$-value is greater than the level of significance $(\mathbf{\alpha}=0.05)$

There is also a significant difference among the mean of each group on the scale of "Work Method," as the p-value (0.0071) suggests. It was found out that in a pairwise comparison, the "Good" group vs. "Very Good" group with $p$-value $=0.1611$ shows that between them, the disparity is non-significant. In contrast, in the "Superior" group vs. "Good" group and "Superior" group vs. "Very Good" group with p-value=0.0021 and pvalue $=0.0068$ (respectively), these suggest that within this pair-wise analysis, the significant differences existed. With the light of these findings, it can be deduced that the level of the performance (Mean=3.999) of the "Superior" performing group when it comes to the scale of "Work Method" is far more different compared to the other group.

If "Delay Avoidance" and "Work Method" are collectively analyzed, there exists a significant difference among the mean of each group on the scale of "Study Habit" as what p-value (0.0007) reveals. Further analysis, still, it was found out that in a pairwise comparison, the "Good" group vs. "Very Good " group with pvalue $=0.0987$ shows that between them, the disparity is non-significant. In contrast, in the "Superior" group vs. "Good" group and "Superior" group vs. "Very Good " group with p-value=0.0002 and p-value=0.0008 (respectively) these suggest that within these pair-wise analysis the significant differences existed. With the light of these findings, it can be deduced that the level of the performance (Mean=4.035) of the "Superior" performing group when it comes to the scale of "Study Habit" is far more different compared to the other groups. It can somehow be drawn into the conclusion that the "Superior" performing group of students highly performed far more compared to the other two identified groups when it comes to the completion of tasks, time management, and study skills.

These findings seconded the motion of the earlier claim (from the discussion on the level of the students' Study Habit and the studies conducted by Singh (2015), and Siahi and Maiyo (2015) that statistically, there is a significant disparity of their among the mean of the group of students in terms of Study Habit.

Moreover, it can also be noticed that there is a significant difference among the mean of each group on the scale of "Teacher Approval" as the p-value (0.0096) is less than the level of significance. It was found out that in a pairwise comparison, the "Good" group vs. "Very Good" group with p-value=0.3923 shows that between them, the disparity is non-significant. In contrast, in the "Superior" group vs. "Good" group and "Superior" group vs. "Very Good" group with p-value $=0.0043$ and p-value $=0.0046$ (respectively), these suggest that within these pair-wise analyses, the significant differences existed. With the light of these findings, it can be deduced 
that the level of the performance (Mean=4.06) of the "Superior" performing group when it comes to the scale of "Teacher Approval" is far more different compared to the other group.

The data also reveal that there is no significant difference among the mean of students when it comes to the scale of "Educational Acceptance" as the p-value (0.0656) is higher than the level of significance. This finding suggests that even if the figure in terms of their mean in the scale of "Educational Acceptance" ("Good: Mean= 3.28", "Very Good: Mean= 3.49", "Superior: Mean=3.9") shows a noticeable difference their approval in educational objectives, practices, and requirements are statistically the same.

However, if "Teacher Approval" and "Educational Acceptance" are collectively analyzed, there exists a significant difference among the mean of each group on the scale of "Study Attitude" as what p-value (0.0159) reveals. It clarifies somehow that, in a pairwise comparison, the "Good" group vs. "Very Good" group with pvalue $=0.2797$ shows that between them, the disparity is non-significant. In contrast, in the "SUPERIOR" group vs. "Good" group and "Superior" group vs. "Very Good" group with p-value $=0.0055$ and p-value $=0.0103$ (respectively) these suggest that within these pair-wise analysis the significant differences existed. With the light of these findings, it can be deduced that the level of the performance (Mean=3.985) of the "Superior" performing group when it comes to the scale of "Study Attitude" is far more different compared to the other groups. It can somehow be drawn into conclusion that the "Superior" performing group of students highly possess far more positive disposition about Teacher Approval (opinions about teacher classroom behavior, management, and methods), and Educational Acceptance (acceptance of educational objectives, practices, and requirements) compared to the other identified groups.

This is encompass on the citation made by Mendezabal (2013) that high-accomplishing understudies had an increasingly uplifting disposition toward study in that they distinguished and responded decidedly to the significant parts of the circumstance they ended up in, while the low-accomplishing understudies would, in general, be critics, responding to the negative parts of concentrate, for example, interruptions and minor disturbances. The high-accomplishing understudies discovered tertiary work an energizing test, acknowledged the confinements, and fit in with the requests made upon them all the more promptly, while the low achievers seemed to need elevated level inspiration.

In totality, it can be verified base from figures that there is a significant difference in "Study Orientation" among the mean of each group of students as what p-value (0.0008) reveals. Further analysis, it was found out that, in a pairwise comparison, the "Good" group vs. "Very Good" group with p-value $=0.1197$ shows that between them, the disparity is non-significant. In contrast, in the "Superior" group vs. "Good" group and "Superior" group vs. "Very Good" group with p-value $=0.0002$ and p-value $=0.0009$ (respectively) these suggest that within these pair-wise analysis the significant differences existed. With the light of these findings, it can be deduced that the level (Mean=3.985) of the "Superior" performing group when it comes to the scale of "Study Orientation" is far more different compared to the other groups. It can somehow be drawn into the conclusion that the "Superior" performing group of students highly performed far more compared to the other two identified groups when it comes to their Study Habits and Study Attitudes.

These findings support the revelation presented in the study of Sikhwari (2016), wherein he stated that there is a significant difference between the study orientation level of the high achieving students and the low achieving students. Furthermore, these conform also to the findings presented by Biswas (2015) that the study orientation level of the high achiever students was better compared to the study orientation of the low achiever students.

\section{CONCLUSION}

As far as the data and the findings are concerned, it can be concluded that the majority of the students academically performed Very Good, and their study orientation generally falls also on the above-average level. There was a significant disparity among the level of the study orientation of the students wherein the study orientation of the highest academically performers are significantly at far with the lower two identified groups. Furthermore, the study orientation of the students has a very significant relationship to their academic performance, wherein students with high study orientation tend to achieve more compared to the students with lower study orientation. 


\section{RECOMMENDATIONS}

The researchers recommend that mathematics students, especially the tertiary students, should develop an effective system of study strategies that will enable them to understand mathematics better and, at the same time achieving more towards their academic performance. Also, they recommend replication of this study specifically on the students' study attitude in terms of students' Teacher Approval is highly recommended in order to seek an answer on how to elevate their attitude towards a more positive one.

\section{Disclosure statement}

No potential conflict of interest was reported by the authors.

\section{Notes on contributors}

Marvin Guinocor - Cebu Technological University, Philippines.

Porferio Almerino - Cebu Technological University, Philippines.

Irene Mamites - Cebu Technological University, Philippines.

Charisma Lumayag - Cebu Technological University, Philippines.

Mary Anne Villaganas - Cebu Technological University, Philippines.

Mae Capuyan - Department of Education, Cebu Province, Philippines.

\section{REFERENCES}

Ajisuksmo, C. R., \& Saputri, G. R. (2017). The influence of attitudes towards mathematics, and metacognitive awareness on mathematics achievements. Creative Education, 8, 486, 497. https://doi.org/10.4236/ce.2017.83037

Americans, W. A. (2009). It doesn't add up African American students' mathematics achievement. Secondary Lenses on Learning Participant Book: Team Leadership for Mathematics in Middle and High Schools, 149. Retrieved from http://bit.ly/2IaUOrL

Bashir, I., \& Mattoo, N. H. (2012). A study on study habits and academic performance among adolescents (1419) years. International Journal of Social Science Tomorrow, 1(5), 1-5. Retrieved from http://bit.ly/2Z2SjNd

Bedel, E. F. (2012). An examination of locus of control, epistemological beliefs, and metacognitive awareness in preservice early childhood teachers. Educational Sciences: Theory and Practice, 12(4), 3051-3060. Retrieved from http://bit.ly/2Z0EwXr

Biswas, S. K. (2015). Study orientation of high and low achievers at secondary level. International Journal on New Trends in Education \& their Implications (IJONTE), 6(4). https://doi.org/10.14738/assrj.210.1355

Blömeke, S., \& Delaney, S. (2014). Assessment of teacher knowledge across countries: A review of the state of research. International perspectives on teacher knowledge, beliefs, and opportunities to learn (pp. 541585). Springer, Dordrecht. https://doi.org/10.1007/978-94-007-6437-8_25

Bong, M. (2004). Academic motivation in self-efficacy, task value, achievement goal orientations, and attributional beliefs. The Journal of Educational Research, 97(6), 287-298. https://doi.org/10.3200/JOER.97.6.287-298

Care, E., Azim, F., Beswick, B., Harding, S. M., Luo, R., Bustos, T., \& Cagasan, L. (2015). Large-scale assessments for use in the Philippines. Retrieved from http://bit.ly/2G0PvYq

Cerna, M. A., \& Pavliushchenko, K. (2015). Influence of study habits on academic performance of international college students in Shanghai. Higher Education Studies, 5(4), 42-55. https://doi.org/10.5539/hes.v5n4p42

Demir, S., Kılınç, M., \& Doğan, A. (2017). The effect of curriculum for developing efficient studying skills on academic achievements and studying skills of learners. International Electronic Journal of Elementary Education, 4(3), 427-440. Retrieved from http://bit.ly/2IoPSPb

Dinglasan, B. L., \& Patena, A. (2013). Students performance on departmental examination: Basis for math intervention program. University of Alberta School of Business Research Paper, (2013-1308). Retrieved from http://bit.ly/2uYhfrk 
Ebele, U. F., \& Olofu, P. A. (2017). Study habit and its impact on secondary school students' academic performance in Biology in the federal capital territory, Abuja. Educational Research and Reviews, 12(10), 583-588. https://doi.org/10.5897/ERR2016.3117

Etcuban, J. O., \& Pantinople, L. D. (2018). The effects of mobile application in teaching high school mathematics. International Electronic Journal of Mathematics Education, 13(3), 249-259. https://doi.org/10.12973/iejme/3906

Fazal, S., Hussain, S., Majoka, M. I., \& Masood, S. (2012). The role of study skills in academic achievement of students: A closer focus on gender. Pakistan Journal of Psychological Research, 27(1), 37. Retrieved from http://bit.ly/2VJS5s8

Ganal, N. N., \& Guiab, M. R. (2014). Problems and difficulties encountered by students towards mastering learning competencies in mathematics. Researchers World, 5(4), 25. Retrieved from http://bit.ly/2X0dJc8

Guner, N. (2012). Using metaphor analysis to explore high school students' attitudes towards learning mathematics. Education, 133(1), 39-48. Retrieved from http://bit.ly/2G4mYBi

Guy, G. M., Cornick, J., \& Beckford, I. (2015). More than math: On the affective domain in developmental mathematics. International Journal for the Scholarship of Teaching and Learning, 9(2), 7. https://doi.org/10.20429/ijsotl.2015.090207

Horstmanshof, L., \& Zimitat, C. (2007). Future time orientation predicts academic engagement among firstyear university students. British Journal of Educational Psychology, 77(3), 703-718. https://doi.org/10.1348/000709906X160778

Hossain, M. (2012). How to motivate US students to pursue STEM (science, technology, engineering, and mathematics) careers. Online Submission. Retrieved from https://eric.ed.gov/?id=ED533548

Iftikhar, S. (2014). The importance of metacognitive strategies to enhance reading comprehension skills of learners: A self-directed learning approach. Journal of English Language and Literature, 2(3). https://doi.org/10.17722/jell.v2i3.83

Kaushar, M. (2013). Study of impact of time management on academic performance of college students. Journal of Business and Management, 9(6), 59-60. https://doi.org/10.9790/487X-0965960

Kelly, D., Nord, C. W., Jenkins, F., Chan, J. Y., \& Kastberg, D. (2013). Performance of US 15-year-old students in mathematics, science, and reading literacy in an international context. First Look at PISA 2012. NCES 2014-024. National Bureau of Economic Research. Retrieved from https://eric.ed.gov/?id=ED544504

Khurshid, F., Tanveer, A., \& Qasmi, F. N. (2012). Relationship between study habits and academic achievement among hostel living and day scholars' university students. British Journal of Humanities and Social Sciences, 3(2), 34-42. Retrieved from http://bit.ly/2P9krtL

Kumar, D. S., \& Nagaraju, K. (2015). Cognitive styles and job satisfaction among high school mathematics teachers. International Journal of Multidisciplinary Approach \& Studies, 2(2), 179-185. Retrieved from http://bit.ly/2uZWdZz

Kunter, M., Klusmann, U., Baumert, J., Richter, D., Voss, T., \& Hachfeld, A. (2013). Professional competence of teachers: Effects on instructional quality and student development. Journal of Educational Psychology, 105(3), 805. https://doi.org/10.1037/a0032583

Leatham, K. R., \& Peterson, B. E. (2010). Secondary mathematics cooperating teachers' perceptions of the purpose of student teaching. Journal of Mathematics Teacher Education, 13(2), 99-119. https://doi.org/10.1007/s10857-009-9125-0

Loon, M., \& Nichol, L. (2015). Confluent learning: Using a design approach to develop cognitive abilities and enhance affective capacities through change management curriculum. Retrieved from http://eprints.worc.ac.uk/4604/

Macher, D., Paechter, M., Papousek, I., Ruggeri, K., Freudenthaler, H. H., \& Arendasy, M. (2013). Statistics anxiety, state anxiety during an examination, and academic achievement. British Journal of Educational Psychology, 83(4), 535-549. https://doi.org/10.1111/j.2044-8279.2012.02081.x

Mahdavi, M. (2014). An overview: Metacognition in education. International Journal of Multidisciplinary and current research, 2(3), 529-535. Retrieved from http://bit.ly/2uXVkRm 
Maltese, A. V., \& Tai, R. H. (2011). Pipeline persistence: Examining the association of educational experiences with earned degrees in STEM among US students. Science education, 95(5), 877-907. https://doi.org/10.1002/sce.20441

Mata, M. D. L., Monteiro, V., \& Peixoto, F. (2012). Attitudes towards mathematics: Effects of individual, motivational, and social support factors. Child Development Research, 2012. https://doi.org/10.1155/2012/876028

Mendezabal, M. J. N. (2013). Study habits and attitudes: The road to academic success. Open Science Repository Education, (open-access), e70081928. Retrieved from http://bit.ly/2UQswIT

Morosanova, V. I., Fomina, T. G., Kovas, Y., \& Bogdanova, O. Y. (2016). Cognitive and regulatory characteristics and mathematical performance in high school students. Personality and Individual Differences, 90, 177-186. https://doi.org/10.1016/j.paid.2015.10.034

Mutai, K. J. (2011). Attitudes towards learning and performance in mathematics among students in selected secondary schools in Bureti district, Kenya (Doctoral dissertation). Retrieved from http://bit.ly/2Gg1HWB

Nasrullah, S., Khan, M. S., Khan, I., \& Afaq, Q. (2015). The factors affecting the students' academic achievements in higher educational institutions. Gomal University Journal of Research [GUJR], 31(1). Retrieved from http://bit.ly/2KoIJRr

Oluwatimilehin, J. T. B., \& Owoyele, J. W. (2012). Study habits and academic achievement in core subjects among junior secondary school students in Ondo State, Nigeria. Bulgarian Journal of Science and Education Policy, 6(1), 155. Retrieved from http://bit.ly/2VDfXO7

Osa-Edoh, G. I., \& Alutu, A. N. G. (2012). A survey of students study habits in selected secondary schools: Implication for counselling. Current Research Journal of Social Sciences, 4(3), 228-234. Retrieved from http://bit.ly/2GfxxCP

Presmeg, N. (2006). Research on visualization in learning and teaching mathematics: Emergence from psychology. In Handbook of Research on the Psychology of Mathematics Education (pp. 205-235). Brill Sense. https://doi.org/10.1163/9789087901127_009

Ronis, D. L. (2008). Problem-based learning for math \& science: Integrating inquiry and the internet. Corwin Press. Retrieved from http://bit.ly/2U1KK5F

Shapiro, S. (1983). Confluent education: Paradigm lost?. Journal of Humanistic Psychology, 23(2), 85-96. https://doi.org/10.1177/0022167883232009

Siahi, E. A., \& Maiyo, J. K. (2015). Study of the relationship between study habits and academic achievement of students: A case of Spicer Higher Secondary School, India. International Journal of Educational Administration and Policy Studies, 7(7), 134-141. https://doi.org/10.5897/IJEAPS2015.0404

Sikhwari, T. D. (2016). Study habits, attitudes, and academic achievement: Comparing Grade 12 learners between two secondary schools. Journal of Educational Studies, 15(2), 43-61. Retrieved from http://bit.ly/2IwDVqV

Singh, P. (2015). Interaction effect of brain hemispheric dominance and study habits on academic achievement in mathematics. IJAR, 1(11), 746-750. Retrieved from http://bit.ly/2X2YnDs

Stover, J. B., Hoffmann, A. F., de la Iglesia, G., \& Liporace, M. F. (2014). Predicting academic achievement: The role of motivation and learning strategies. Problems of Psychology in the 21st Century, 8(1), 71-84. Retrieved from http://bit.ly/2uYvcWh

Wei, M. H., \& Dzeng, H. (2014). A comparison study of math education and math performance between Asian countries and the United States. Journal of Socialomics, 3(02), 2167-0358. https://doi.org/10.4172/21670358.1000111

West, P. E., Lunenburg, F. C., \& Hines III, M. T. (2014). Teacher quality variables and efficacy for teaching minority students. Education Leadership Review of Doctoral Research, 1(1), 39-57. Retrieved from https://eric.ed.gov/?id=EJ1105731 